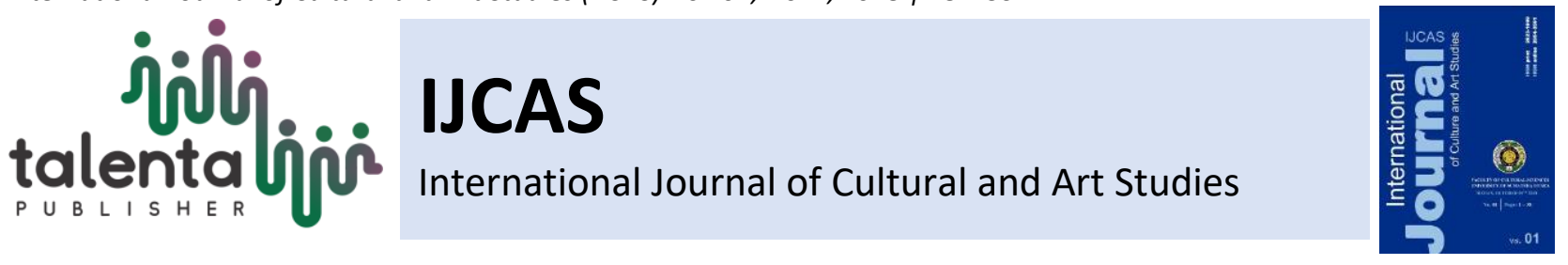

\title{
The Maritime Historical Background of Bogak Port (8-20 Century), Tanjung Tiram District, Batubara Regency, North Sumatera Province
}

\author{
Lila Pelita Hati ${ }^{*}$, Fitriaty Harahap ${ }^{2}$,Suprayitno ${ }^{3}$, Mokhtar Saidin $^{4}$. \\ 1,2,3 Universitas Sumatera Utara \\ ${ }^{4}$ Universiti Sains Malaysia
}

\begin{abstract}
On January 2008 in the bank of the Bogak Beach, in front of Fisherman Housing, Dusun XII Bogak Village, Tanjung Tiram District, Batubara Regency, North Sumatera Province a boat was found. It was already researched that it was a heritage and related to that area in the 18th century. It was a trade line for traders and fishermen from foreign countries sailed to Sumatera. Not only boat but also Chinese ceramic and coins found in 1734, 1752, 1760, 1780, 1781, 1788 and 1790. This paper tries to describe the role of Pantai Bogak Port during $18^{\text {th }}$ Century until $20^{\text {th }}$ Century in the east coast maritime, and to research the archaeological and historical resources in Tanjung Tiram Regency; to look for the authenticity from Batubara Regency, North Sumatera Province. It can be a pride for Indonesia and give a horizon about the activities and the cultural human history in $18^{\text {th }}$ century until $20^{\text {th }}$ century. The data were obtained from collecting data observation in the field, and then the data were analyzed to give recommendation. The information process was done by collecting data about historical data and the archaeological. The primary data were obtained through observation, meanwhile the secondary data were obtained from rapport, inventories register, study results, and libraries.
\end{abstract}

Keywords: Ancient Port, Boat, Cultural Heritage

Received 15 May 2018 | Revised 23 July 2018 | Accepted 18 August 2018

\section{Introduction}

Silau or Asahan in $18^{\text {th }}-19^{\text {th }}$ century was the central of trade commodity from Toba area (McKinon, 1984: 329-330). The potential commodity is getah perca (sapotaceae) or gota ni meang (Bataknese language), specially for protected the leak of the boat or canoe. At that era, Asahan District still reign by the Batubara Kingdom, and reign by the $12^{\text {th }}$ famous king, Datu Muhammad Yuda and yang bergelar Al Sridiraja. Datu Muhammad Yuda trade to Malaka, Singapura and the others area to had fund for built the Niat Lima Laras (1907-1912) palace.

\footnotetext{
*Corresponding author at: Department of English Faculty of History Sciences University Of Sumatra Utara, Medan, Indonesia 20155. 
In colonial era in Indonesia, East Sumatera include Asahan became district with Bengkalis, Riau as the capital city. It was an Afdeling (Regency) Asahan with the controleur in Tanjung Balai [1], and Dutch believed to Batubara Kingdom. At that time the famous kingdom was Datu Muhammad Yuda (Al Sridiraja), as the $12^{\text {th }}$ ancestor. He was traded to Malacca, Singapore and other places to collect money for building new palace, the Niat Lima Laras Palace (1707-1912). The palace located in Limalaras Village, Tanjung Tiram District, Asahan Regency. After Datu Muhammad Yuda passed away in 1919, the ancestors stayed there, but in 1970 that palace was not took care anymore and no one stayed in the palace.

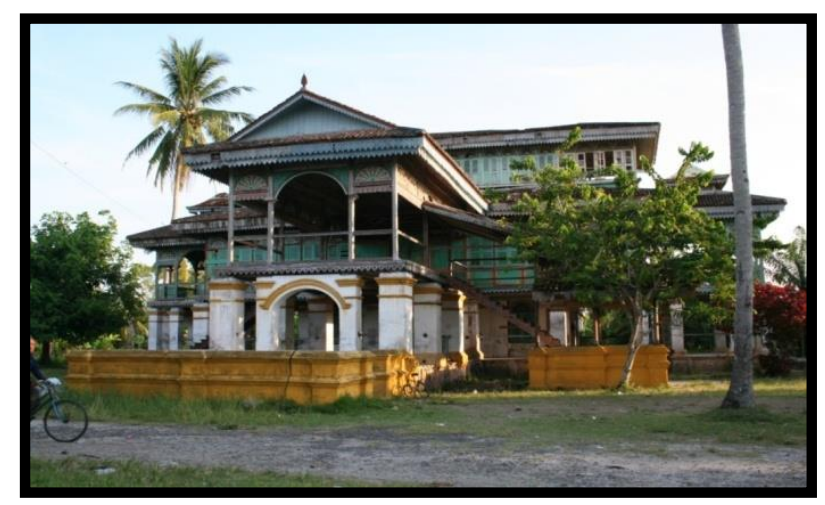

Figure 1. Niat Lima Laras Palace

According to regulation number 8 of the year 1956 about Autonomy Established Great Areas, and also number 19 of the year 1956 about Autonomy Established Small Areas, it is stated that the reign of king or sultan had been finished. The Batubara Kingdom became Asahan Regency territory included Tanjung Tiram. Because of this change, Bogak Port is remaining. This is one the reason why this paper should be written.

This paper aims to describe Bogak Port history from $18^{\text {th }}$ to $20^{\text {th }}$ Century during Dutch reign and Batubara Kingdom reign and to find out the historical and archaeological traces in Tanjung Tiram District in east coast maritime.

The finding of boat, ceramics, coins and Istana Lima Laras Palace becomes the source of data that inform about ancient living in east coast of Sumatera Island, which can be a potentiality for the Asahan District, Tanjung Tiram Regency, and North Sumatera Province authenticity. 


\section{Bogak Port}

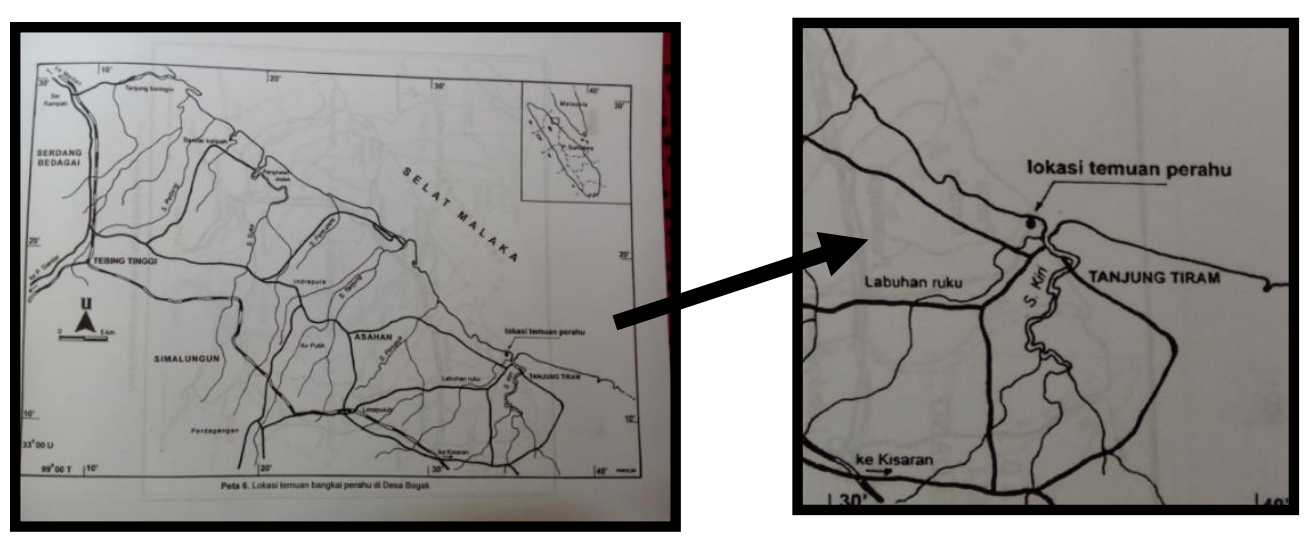

Figure 2. Map of Bogak

This is the map of Bogak in the east coast of Sumatera Island. The location of boat has been founded not far from Malacca Straits, near Tanjungtiram Left River and Tanjungtiram Right River. Figure 3 showed the boat which was found in Bogak Village, Tanjung Tiram District, and according of Carbondating (C14) that it was about $240 \pm 178$ years ago [2]. From all the long of body Bogak boat, it is showed the round form in the middle and strength a long length in the two points. By using technology, it is showed that it used pickax (petel/belincung). It can be described that whole wooden was cut into half, and the handle of boat was made with 7 centimeters thick. This boat construction showed combination of boats from Indonesian Archipelago and from the western. The keel of boat in the form of lesung boat showed the archipelago identifying mark, and the other park showed from western influence. The function of the boat is to carry commodity or trade, but not as a ferry, and this boat can load the weight totally around 15 tons.

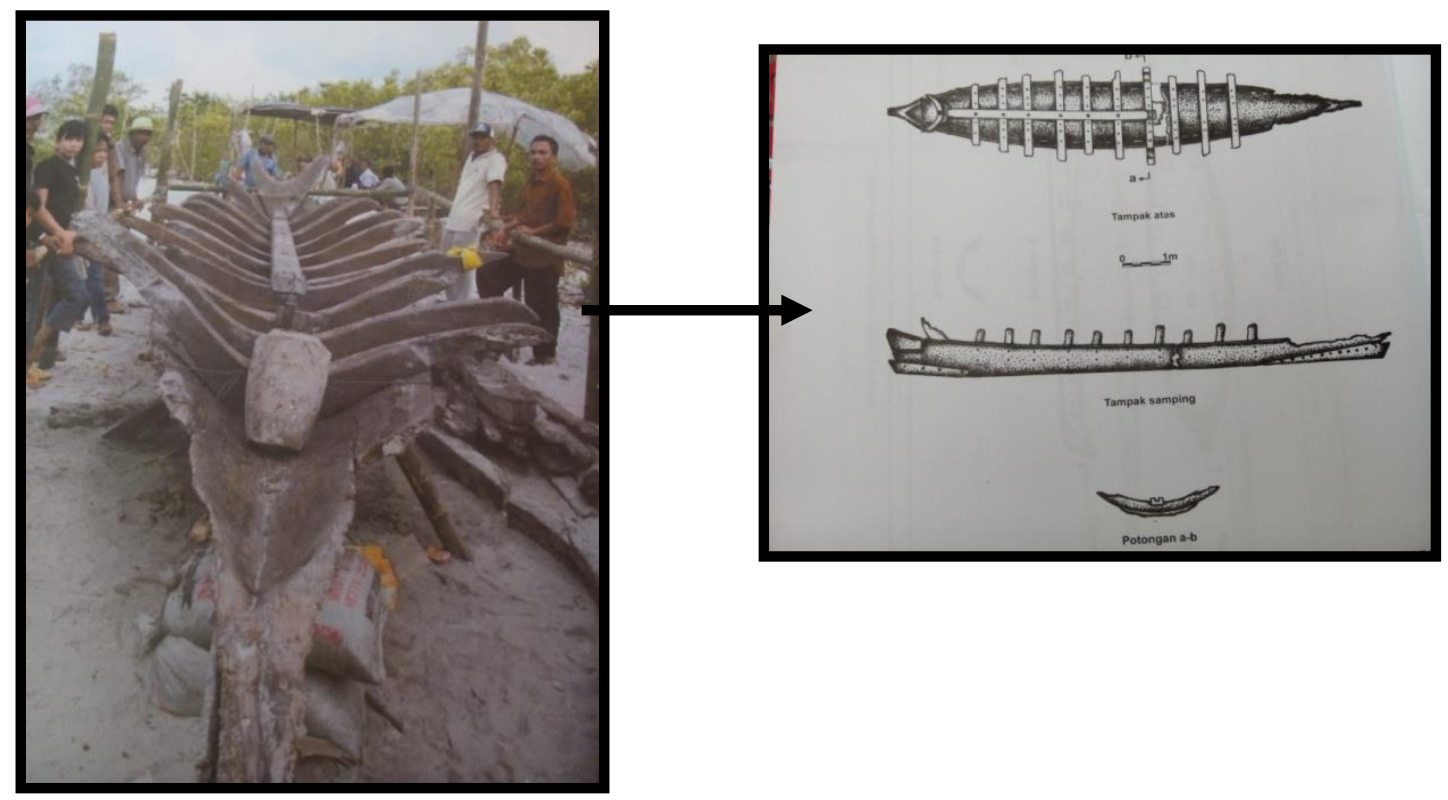

Figure 3. Bogak Boat 
Another finding in Bogak boat was some coins made in 1734, 1752, 1760, 1780, 1781, 1788 and 1790.

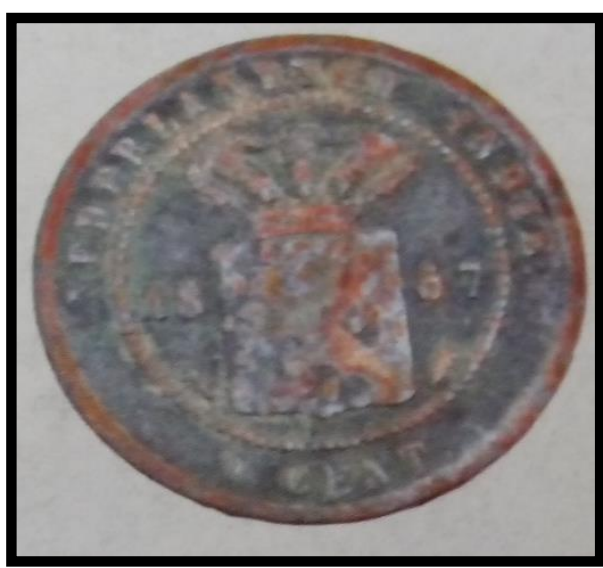

Figure 4. Netherlands East Indies Coins (The Front Side)

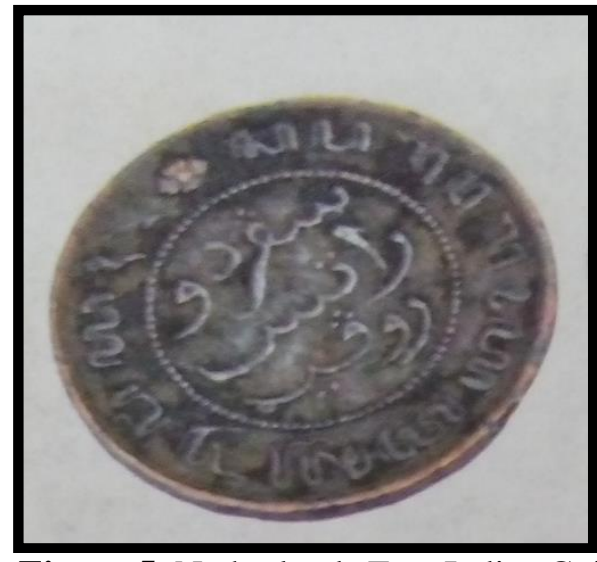

Figure 5. Netherlands East Indies Coins (The Back Side)

This coin was made from silver and the value about 1/20 Gulden, and was produced by Koninklijke Leidong Munt, Utrecht, Netherland. The front side showed an inscriptionNEDERLANDSCH INDIES, and between the throne pictures of the year 1887, in the below side it is found a word 'CENT'. In the back side of the coins were script with two alphabets, Javanese alphabet and Arabic Alphabet. The writing in Javanese was sapnyaba rayutus rupiyah and the writing in Arabische was sakdu ratus rupiyah which both mean seratus rupiah.

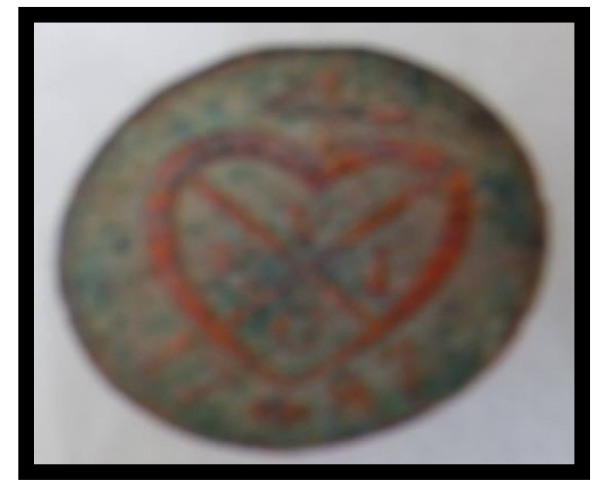

Figure 6. EIC Coin

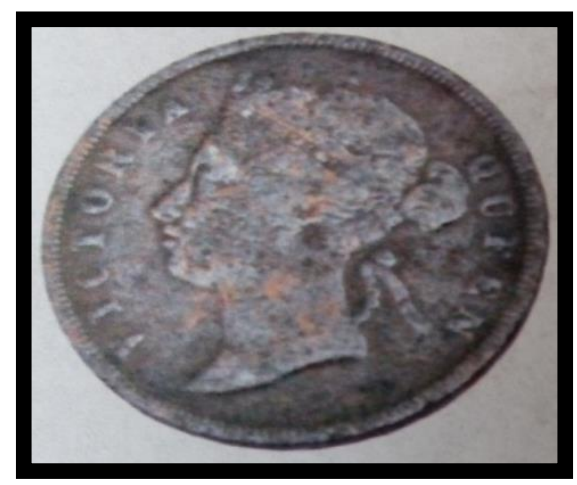

Figure 7. Victoria Queen Coin
In the front side of the coin shown in figure 6 presents English Kingdom symbol, and EIC stands for East India Company (English trade), and also the script 1887 conveying the year, but the back side of the coin is unclear.

In the front side of the coin shown in figure 7 presents the picture of woman, and around it the name of the Victoria Queen was written. This coin was the first mold coin from Europe made from bronze. 


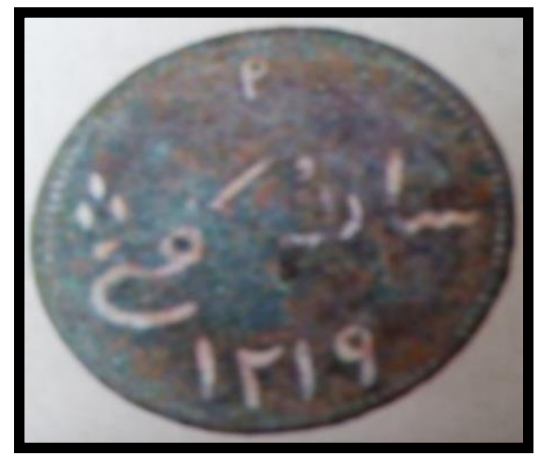

Figure 8. Arabic Coin

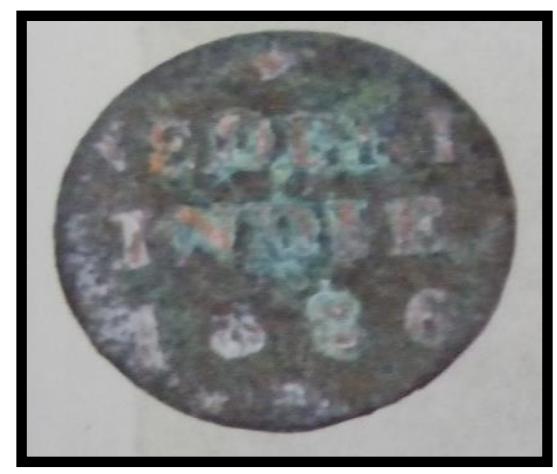

Figure 9 shows coin with the script showing Nederland Indie with the year 1886, but another side of the coin cannot be read.

Figure 9. Nederland Indie coins

Reference [3] stated that the aim to study history is to be wise before something happens. Thus, history of a country is very important to develop the value of local culture, especially to widen and bring some patterns in national culture. Local historical research can build local loyalty for national struggle to defense the Republic of Indonesia.

According to the observation done, the wood shavings existed as the proof in the area where the boat was found. It could be known that the boat was made in that area. It was connected to the place where the boat found, in the bank of the river, indicated from the age of the sediment. It is presumed that it was casted strongly, covered by sediment material, became thick, and then the ablation made the boat float to the surface.

The Radio Carbon analysis with C14 which still remained on the wood helps to provide reliable data. The results show that $240 \pm 120 \mathrm{BP}(1950)$, that is $240 \pm 178$ years ago, or that the remained sunken boat was from 200 years ago [4]. The Bogak boat was a cultural heritage remained and was connected to everyday life of the society in the 18th centuries. It was the time where the sailors and the traders from many countries embellished the economic living and developed the multiethnics such as Javanese, Tamil people, and the Chinese in that area, which became North Sumatera Society. When that area changed into rubber and other plantations, they became dock worker or coolie, porter or labor. 
Asahan Kingdom was reign in Islam Period in Indonesia. In the politic side, the change could happen, like the last reign of Majapahit Kingdom and then came Demak Kingdom as the first Islam Kingdom in Java.

Be equal to shipping and trading expanded under Majapahit Kingdom influence - it is regarded as agrarian kingdom - the Islam influence in Indonesian Archipelago became more expanded. In Java, the opportunity of sea trade existed before 15 th centuries. It was believed that the proselytization Islam religion was the traders and the seamen [4], then they followed the harbor cities, especially along North Java Coast. In fact, during 16th centuries, Demak was a trade city whose ruler had embraced Islam. The great influence also strongly grew in the eastern Indonesian Archipelago.

The Islamic influence spread larger than India influence. In the early period, Islamic culture did not grow in eastern Indonesian Archipelago. The change and the expansion of the Islam made cultural diversity with the cultural influence of Hinduism and Buddhism. The subordinate is not only in the economy, politic and social sector, but also in the religion sector.

\section{Conclusion}

The objects found from Bogak Beach have historical and archaeological value and should be preserved. It is a pride for Indonesia, especially for Asahan Regency. The main purpose of this research is to give benefit for science development which is connected with History Science, Archeology Science, Environment Science, and science connected to tourism, especially to develop the history. Hopefully the local people will consider about developing maritime history in their area.

The Bogak boat is a potential and an attractive object used as source of data to know more about the social life of the community living in the east coast Sumatera Island, for examples, the way they lived, socialized, and traded. It also can inform some foreign tribes coming and living together with them.

The really essential problem to be solved is the underwater remains cultural interaction between Indonesia, India, Arab, China and Europe. Previously, the study potentially helps to uncover the dark side of ancient migration, likes the human migration from Southeast Asia to Pacific. In the other scope, underwater remains potentially to show the capability of Indonesian Archipelago boats sailed. It proved that our ancestor has a navigation knowledge which makes them possible sailed to somewhere across widely the ocean. Moreover, it can increase our comprehension about the shipping and trading regulation which allows the shipping and trading grow rapidly and orderly. It also can explain the existence of Republic Indonesia related to the borderline connected 
to the water territory. Underwater archaeology study for other objects can give contribution and stressing, especially in politic, cultural and social efforts dealing with borderline.

Potency, problems and prospect on underwater remained in Indonesia remind and encourage about what the expert has done and what should be done about underwater archaeology remains in Indonesia, included what they expect from the people and how they respond toward these aspects.

The Bogak boat as Archaeological remains and a living culture can also be an attractive object destination for the tourists and for other purposes, for examples, economy, politic, and sciences. Tourism sector should be developed based on the study on natural, cultural, and historical potentiality of Bogak Village. 


\section{REFERENCES}

[1] Jufrida, Batubara, Perjalanan Sejarahnya di Pesisir Timur Sumatera. Dalam Berkala Sangkhakala, Nomor : 09/2001, Juni 2001, Medan : Balai Arkeologi Medan. 2001.

[2] Koestoro, L. Partanda, et all. Subfosil dan Bangkai Perahu Di Pesisir Timur Sumatera Utara. Dalam Berita Penelitian Arkeologi Nomor 20. Medan: Balai Arkeologi Medan, 2006.

[3] J. Anderson, Mission to East Coast Sumatra : A Report, London : Blackwood, 1926.

[4] Koestoro, Lucas Partanda, Teknik Survei dan Ekskavasi dalam Arkeologi Bawah Air, in Berkala Arkeologi Sangkhakala Nomor 07, Medan: Balai Arkeologi Medan, 2000.

[5], H.J. Graaf \& Th. G Th. Pigeaud, Kerajaan-kerajaan Islam Pertama Di Jawa, Jakarta: Grafiti Pers, 1985.

[6] J. Breman, Menjinakkan Sang Kuli. Politik Kolonial Pada Awal Abad Ke-20. Jakarta: KITLV dan Pustaka Utama Grafiti, 1997.

[7] Husny, Tengku H.M. Lah, Lintasan Sejarah Peradaban dan Budaya Penduduk Melayu Pesisir Deli Sumatra Timur, 1612 - 1950, Jakarta: Departmen Pendidikan dan Kebudayaan, 1978.

[8] -------------, Rempah dan Perahu di Perairan Sumatera dalam Ungkapan Arkeologis dan Historis, in Jurnal Arkeologi Indonesia Nomor 3. Jakarta: Ikatan Ahli Arkeologi Indonesia, 2005.

[9] T. L. Sinar, Sari Serdang, Medan: Perwira, 1971.

[10] --------, Sumatera Utara Di Bawah Kekuasaan Hindia Belanda, Jilid I, Medan:Tp, 1975.

[11]--------, Sejarah Medan Tempoe Doeloe, Medan: Perwira, 1991.

[12] R. Thaib, 50 Tahun Kotapraja, Medan Jawatan Kotapraja I, 1959. 